\title{
Telomere Length Determination Based on Different Sex and Leaf Development of Snake Fruit (Salacca zalacca GART. VOSS.) Revealed by Polymerase Chain Reaction
}

\author{
Rima Indhirawati* and Aziz Purwantoro \\ Department of Agronomy, Faculty of Agriculture, Universitas Gadjah Mada \\ Jln. Flora no. 1, Bulaksumur, Sleman, Yogyakarta 55281, Indonesia \\ *Corresponding email: rima.indhi@gmail.com
}

\begin{abstract}
Telomere has special roles at the end of eukaryotic chromosomes consisting of repeated DNA sequences. It protects chromosomes and DNA from damage. The plant sex and the leaf development may change in telomere length. Snake fruit (Salacca zalacca GART. VOSS.) is dioecious plants that have female and male organs on separate plants. The research aimed to determine the telomere length of snake fruit from different plant sex and the leaf development. In this research, we observed telomere length in snake fruit (female and male plants) using Polymerase Chain Reaction (PCR) procedure. The results from this research showed that telomere lengths of male and female were equal. Telomere lengths in the leaf development showed that younger leaves of both male and female leaves were longer compared to older and dried leaves.
\end{abstract}

Keywords: Telomere, senescence, gender

\section{INTRODUCTION}

The aging is a process that occur in all of the cells. Aging and death are closely related to telomeres. In the chromosomes at the end of the eukaryotic cell, there is a segment of DNA called telomeres (Wong and Collins, 2003). Telomere consists of a specific sequence of nucleotides. Most plants have TTTAGGG sequence. Telomeres have an important role to protect DNA from damage and maintain chromosome stability in every cell division (Greider and Blackburn, 1996; Shay et al., 2001).

Changes of telomere length (shortening and lengthening) are linked as markers for cell division and aging processes (senescence) in cells (Flanary and Streit, 2003). Telomere length is affected by the age of the cell. The length of the human telomere shortens proportionally with age (Purwaningsih, 2010). Senescence will result in shortening of telomeres (Bernadotte et al., 2016). In addition, sex differences also have different telomere lengths. Telomere length in men is shorter than women (Mayer et al., 2006). The research of $\mathrm{Mu}$ et al. (2015) on the telomere length of the dioecious plant stated that the male willow has a shorter telomere length than the female and the female ash has a longer telomere than the male (Mu et al., 2015).

It is necessary to conduct a research using other dioecious plants to find out whether differences in telomere lengths that occur in leaf development and sex will occur in all dioecious plants. In addition, studies related to telomere lengths in different angiosperms of sex are still not widely practiced (Mu et al., 2015). The dioecious plant that is often found in Indonesia and other tropical countries is snake fruit. This research aimed is to determine telomere length of snake fruit on leaf development and sex difference with Polymerase Chain Reaction (PCR).

\section{MATERIALS AND METHODS}

Snake fruit (Pondoh variety) aged about 25 years (three male and female plants) were chosen as experimental materials. Samples of young, older, and dried leaves were collected from Turi, Sleman, Yogyakarta. This research had two stages of observation; the first was to observe the leaf condition of the 
sample using chromameter to measure the color intesity. Color intensity analysis with chromameter obtained L* (lightness), a* (redness), $b^{*}$ (yellowness). $\mathrm{L}^{*}$ color parameter denoted the darkness of a color from 0 (black or dark) to 100 (white or light), a* color parameter measured from 0 to 80 , positive $(+)$ was indicated by red and negative (-) was indicated by green, and $b^{*}$ was from 0 to 70 , positive $(+)$ was indicated by yellow and negative (-) was indicated by blue color (Suyatma, 2009).

Detection of telomere length with Polymerase Chain Reaction (PCR) begins with leaf DNA extraction using CTAB method (Doyle and Doyle, 1990). The leaves were weighed and cut by 0.10 .5 grams, then crushed with mortar and added with $800 \mu \mathrm{l}$ of CTAB buffer solution which was previously incubated in a water bath at $65^{\circ} \mathrm{C}$ for 30 minutes. The CTAB solution consisted of $2 \%$ CTAB, $1.4 \mathrm{M} \mathrm{NaCl}, 100 \mathrm{mM}$ Tris-HCl pH 8, 20 mM EDTA pH 8, and 1\% PVP-40, and $1 \%$ mercaptoenol).

The mixture was incubated in a water bath at $65^{\circ} \mathrm{C}$ for 60 minutes and in every 10 minutes was turned back to keep it homogeneous. After incubation, each sample was added with $500 \mu$ of a mixture of 24 chloroform: 1 isoamic alcohol (CIAA) and vortex for $5 \mathrm{~min}$ and then centrifuged for 15 minutes at a rate of $12,000 \mathrm{rpm}$. The forming supernatant was carefully removed and transferred to a new microtube and recorded in volume. $3 \mathrm{M}$ sodium acetate was added with $1 / 10$ of the supernatant volume and mixed well. Cold isopropanol was added with $2 / 3$ of the total volume (supernatant + sodium acetate) and mixed well by flipping it through the tube. The mixture was kept in the freezer at $4{ }^{\circ} \mathrm{C}$ for $1-24$ hours. The mixture was centrifuged at a rate of $12,000 \mathrm{rpm}$ for 10 minutes. The supernatant was removed and the precipitated DNA was washed with $500 \mu \mathrm{l}$ of ethanol $70 \%$ and centrifuged for five minutes at a rate of $12,000 \mathrm{rpm}$. The supernatant was discarded and the precipitate of the DNA was aerated, then stored in the refrigerator at $4^{\circ} \mathrm{C}$.

DNA was quantified using GeneQuant to determine the concentration and purity of the obtained DNA. Dilutions were performed to obtain the required DNA concentration in the amplification protocol (PCR). Optimization of the primer annealing temperature was carried out at a temperature of $50{ }^{\circ} \mathrm{C}$ to $69^{\circ} \mathrm{C}$. DNA amplification was done by polymerase chain reaction (PCR) to multiply DNA sequences and it used telomere primer of Arabidopsis thaliana (CCCTAAACCCTAAACCCTAAACCCTAAACC). Table 1 presents the stages of the DNA amplification reaction. The
Table 1. DNA amplification stages

\begin{tabular}{llcc}
\hline No. Stages & $\begin{array}{c}\text { Temperature } \\
\left({ }^{\circ} \mathrm{C}\right)\end{array}$ & $\begin{array}{c}\text { Time } \\
\text { (minutes) }\end{array}$ \\
\hline 1 & Pre-heating & 94 & 5 \\
2 & Denaturation & 94 & 0.5 \\
3 & Annealing & $\begin{array}{c}\text { chosen } \\
\text { temperature }\end{array}$ & 1.5 \\
4 & Elongation & 72 & 0.5 \\
5 & Final Elongation & 72 & 7 \\
\hline
\end{tabular}

amplification result was electrophoresed in 100 volts for $55 \mathrm{~min}$ using $1.5 \%$ agarose in electrophoresis tank containing $\mathrm{pH} 8 \mathrm{TBE}$ buffer which was heated in microwave until it was completely dissolved, then added with $4 \mu$ fluorosafe DNA staining. Furthermore, agarose was removed from the electrophoresis tank and visualized using UV light and photographed with a digital camera.

Telomere length was measured by the length of bands of amplification. Data analysis for leaf color intensity and telomere length was analyzed by variance analysis with $95 \%$ confidence level. If there is a significant difference then it would proceed to Tukey Test using SAS (Statistical Analysis System for Windows 9.1.3) software.

\section{RESULTS AND DISCUSSION}

Young leaves were collected from the light green youngest leaves that had been opened perfectly (first frond). Older dark green leaves were collected from the fourth frond. Dried brownish yellow leaves were collected from the seventh frond. The appearance of various leaf development in male and female snake fruit is presented in Figure 1.

The color intensity results of female and male leaves are presented in Table 2 . The $\mathrm{L}^{*}, \mathrm{a}^{*}$, and $\mathrm{b}^{*}$ values of male snake fruit leaves were $44.34 ;-0.32$;

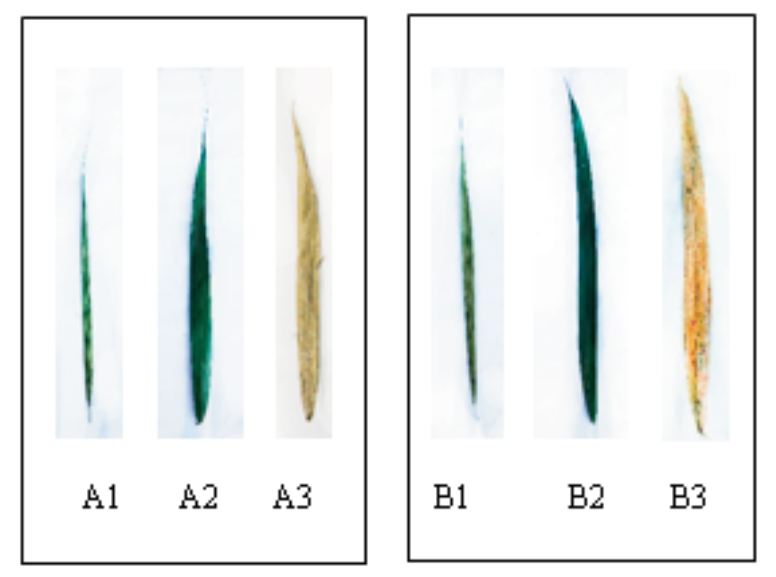

Figure 1. Leaves of male snake fruit (A) and female snake fruit (B): young (1), older (2), and dried (3) 
Table 2. Color intesity of snake fruit leaf (female and male)

\begin{tabular}{lccc}
\hline \multirow{2}{*}{ Snake Fruit } & \multicolumn{3}{c}{ Color intensity } \\
\cline { 2 - 4 } & $\mathrm{L}^{*}$ & $\mathrm{a}^{*}$ & $\mathrm{~b}^{*}$ \\
\hline Male & $44.34 \mathrm{a}$ & $-0.32 \mathrm{a}$ & $15.54 \mathrm{a}$ \\
Female & $45.30 \mathrm{a}$ & $0.54 \mathrm{a}$ & $16.32 \mathrm{a}$ \\
\hline Remarks: The means in one column and row followed by the same letter were not significantly \\
& different according to Tukey $(\alpha \%)$
\end{tabular}

Table 3. Color Intensity of snake fruit leaf on various leaf development

\begin{tabular}{lccc}
\hline \multirow{2}{*}{ Leaf Development } & \multicolumn{3}{c}{ Color intensity } \\
\cline { 2 - 4 } & $\mathrm{L}^{*}$ & $\mathrm{a}^{*}$ & $\mathrm{~b}^{*}$ \\
\hline Young & $42.68 \mathrm{~b}$ & $-5.49 \mathrm{~b}$ & $20.25 \mathrm{a}$ \\
Older & $38.86 \mathrm{c}$ & $-2.78 \mathrm{~b}$ & $15.15 \mathrm{ab}$ \\
Dried & $52.92 \mathrm{a}$ & $8.60 \mathrm{a}$ & $12.39 \mathrm{~b}$ \\
\hline
\end{tabular}

Remarks: The means in one column and row followed by the same letter were not significantly different according to Tukey ( $\alpha$ 5\%)

and 15.54 respectively. The $\mathrm{L}^{*}, \mathrm{a}^{*}$, and $\mathrm{b}^{*}$ values of female snake fruit leaves were 45.30; 0.54; and 16.32 respectively. $L^{*}, a^{*}$, and $b^{*}$ values between male and female leaves were not significantly different.

The various leaf development results are presented in Table 3. The highest $L^{*}$ value leaves were the dried leaves (52.92). The young leaves had higher $\mathrm{L}^{*}$ value (42.68) than the older leaves (38.86), so the dried leaf had lighter color than the older and young leaves. $\mathrm{L}^{*}$ indicated color saturation, since the dried leaves experienced a reduction in the color density causing the color to become lighter. High pigment content affected brightness (Wahyuni and Widjanarko, 2015). The older leaves had high chlorophyll (green pigment), so it had a lower lightness than the young and dried leaves. Further test results showed that $\mathrm{L}^{*}$ value of snake fruit leaves were significantly different in young, older, and dried leaves.

The young and older leaves had negative $\mathrm{a}^{*}$ color parameter which were -5.49 and -2.78 , while dried leaves had positive $a^{*}(8.60)$. The value of $a^{*}$ in young and older leaves were negative indicated by the color tended to be green. The $\mathrm{a}^{*}$ values of snake fruit leaves were different significantly in young leaves with dried leaves and the older leaves with dried leaves.

The young leaves had higher value of $b^{*}(20.25)$ than older leaves (15.15) and dried leaves (12.39), so the young leaves tended to be yellow compared to older and dried ones. The $b^{*}$ values of snake fruit leaves were different significantly in young leaves with dried leaves.

Leaf is one part of the plant that can be aging because it has a limited life. The process of photosynthesis is influenced by the age of the leaves which then affects the leaf color changes, because there are pigments associated with leaf color in photosynthesis (Susanto, 2008). The leaf development increases leaf photosynthesis ability at the beginning, then decreases along with the senescence process caused by chlorophyll recast and decreasing of chloroplast function. The process of deciduous leaves will be followed by changes in leaf color. Young leaves change color into dark green leaves. The older the green, the higher the chlorophyll content, and vice versa. Furthermore, the older leaves will turn color again into yellowish and then into brownish red. Afterwards, the leaves will fall. As the leaves progress, the ability of the leaf photosynthesis will also increase and then begin to decline slowly (Sestak, 1981). These color changes can occur because the chlorophyll content found in older leaves decrease. The lower chlorophyll content will cause the photosynthesis rate to decrease. The development of leaves is characterized by a change of light green to dark green along with the synthesis of chlorophyll b formed from chlorophyll a. Older dark green leaves have chlorophyll content of $72 \%$ larger than the light green leaves (young leaves) (Wolf and Price, 1960 in Pandey and Sinha, 1979). The senescence process produces reactive oxygen species (ROS) in high quantities, as well as the increase in DNA damage due to oxidation (Chen et al., 1995; Song et al., 2005). ROS is known to cause damage to lipids, proteins, and DNA that will accelerate the aging process. According to Furumoto et al., (1998); 


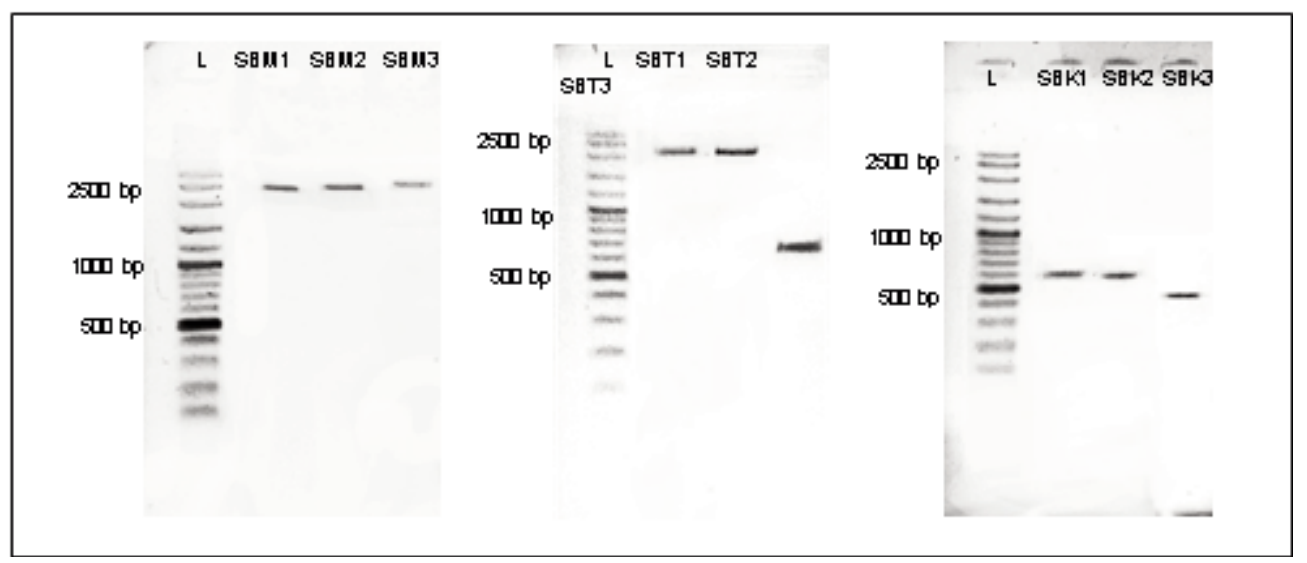

Figure 2. DNA amplification of female leaves (SB): young (M), older (T), and dried (K) Remark: $\mathrm{L}=$ ladder, $1-3=$ sample number

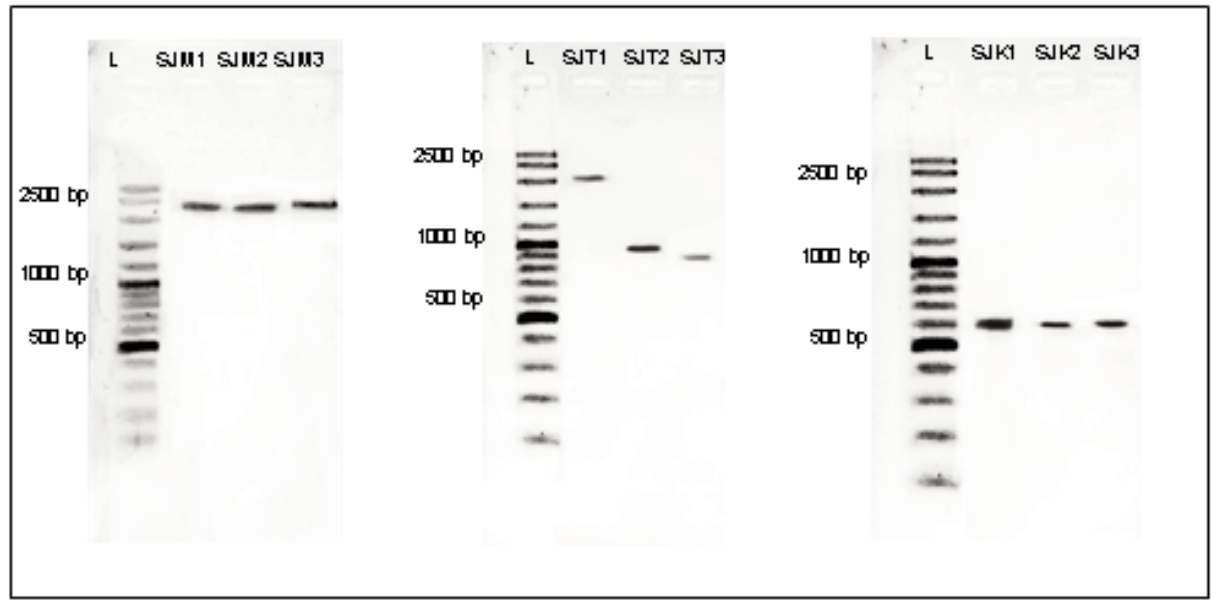

Figure 3. DNA amplification of male leaves (SJ): young (M), older (T), and dried (K)

Remark: $\mathrm{L}=$ ladder, $1-3=$ sample number

Table 4. Telomere Length of Snake Fruit

\begin{tabular}{|c|c|c|c|c|c|c|c|c|c|c|c|c|}
\hline \multirow{3}{*}{$\begin{array}{l}\text { Snake } \\
\text { Fruit }\end{array}$} & \multicolumn{12}{|c|}{ Telomere Length of Leaf (bp) } \\
\hline & \multicolumn{4}{|c|}{ Young } & \multicolumn{4}{|c|}{ Older } & \multicolumn{4}{|c|}{ Dried } \\
\hline & 1 & 2 & 3 & Mean & 1 & 2 & 3 & Mean & 1 & 2 & 3 & Mean \\
\hline & 2,500 & 2,500 & 2,600 & 2533.33 & 2200 & 2200 & 700 & 1700 & 600 & 600 & 450 & 550 \\
\hline & 2,400 & 2,400 & 2,500 & 2433.33 & 2100 & 950 & 850 & 1300 & 600 & 600 & 600 & 600 \\
\hline
\end{tabular}

Lorenz et al., (2001); Saretzki and von Zglinicki, (2002); von Zglinicki, (2002) this oxidative compound can also speed up telomere shortening.

\section{Detection of Telomere Length}

The telomere length was measured by the length of the bands amplified by male (Figure 2) and female (Figure 3). The telomere length of female leaves was 1,594.4 bp and that of male leaves was 1,444.4 bp. The telomere length between male and female leaves were not significantly different. Telomere length between female and male snake fruit leaves showed no significant difference. The results

of research on dioecious plants, either male or female in Ginkgo biloba also showed similar results (Song et al., 2010). Riha et al. (1998) also showed the same length of telomere between the male and female Melandrium albums. While the female ash had a shorter telomere than males, the female willow had longer telomeres than males (Mu et al., 2014). According to Song et al. (2010), further research on telomere length between males and females is still needed.

The telomere length of young, older, and dried leaves decreased (Figure 4). Telomere length of snake fruit in young leaves was $2,483.3 \mathrm{bp}$, in older leaves was $1,500 \mathrm{bp}$, and in dried leaves was $575 \mathrm{bp}$. Further test results showed that telomere length of snake fruit leaves were significantly different in young, older, and dried leaves. The older the leaves, the more shortened the telomere would be. This is 


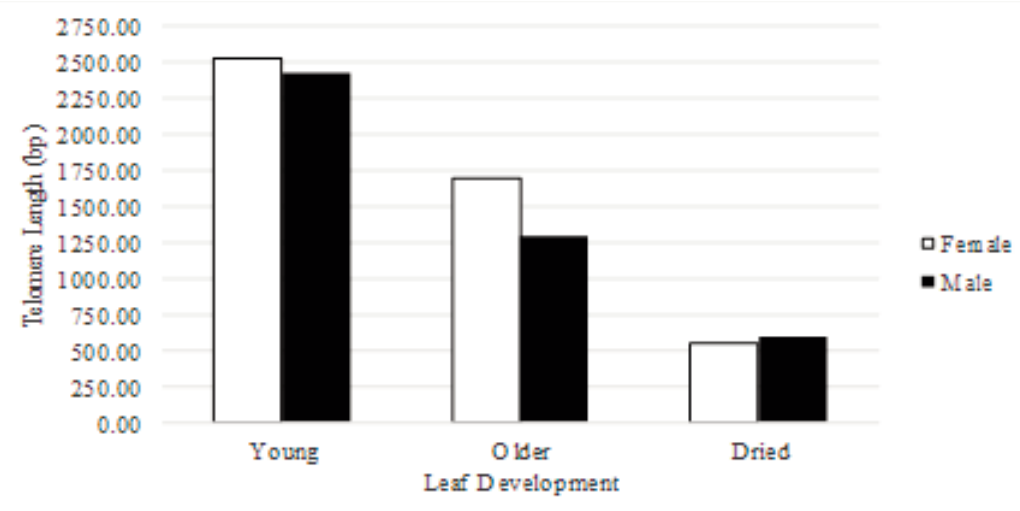

Figure 4. Histogram of telomere length of female and male snake fruit leaf on various leaf development

Table 5. Telomere Length of Male and Female Snake Fruit Leaves

\begin{tabular}{ll}
\hline Snake Fruit & Telomere Length (bp) \\
\hline Male & $1,444.4 \mathrm{a}$ \\
Female & $1,594.4 \mathrm{a}$ \\
\hline
\end{tabular}

Remarks: The means in one column and row followed by the same letter were not significantly different according to Tukey ( $\alpha$ 5\%)

Table 6. Telomere Length on Various Leaf Development

\begin{tabular}{ll}
\hline Snake Fruit & Telomere Length (bp) \\
\hline Young & $2,483.3 \mathrm{a}$ \\
Older & $1,500 \mathrm{~b}$ \\
Dried & $575 \mathrm{c}$ \\
\hline
\end{tabular}

Remarks: The means in one column and row followed by the same letter were not significantly different according to Tukey ( $\alpha 5 \%)$

consistent with the research results on Ginkgo biloba that had shortened telomeres in older leaves (Song et al., 2010), as well as willow and ash plants in older leaves (Mu et al., 2014).

The older leaves of female snake fruit in sample 1 was $2,200 \mathrm{bp}$, in sample 2 was $2,200 \mathrm{bp}$, and in sample 3 was $700 \mathrm{bp}$. The older leaves of male snake fruit in sample 1 was $2,100 \mathrm{bp}$, in sample 2 was $950 \mathrm{bp}$, and in sample 3 was $850 \mathrm{bp}$. The older leaves of female and male snake fruit showed varying telomere lengths. It was presumed that inter-individuals had physiological differences related to aging. Based on research by Liang et al. (2014) in Panax ginseng, it was indicated that there was a complex relationship between telomere length and plant growth and it might be affected by environmental factors and telomerase activity.

Variation in telomere lengths might occur due to the relationship between telomere length and telomerase enzyme activity. The enzyme had been observed in several plant species (Fajkus et al. 1996, Kilian et al. 1998, and Mu et al., 2015). In maize and barley, telomerase activity was suppressed during tissue differentiation (Kilian et al., 1998), so telomeres were shortened due to end-replication problems (Kilian et al. 1995; Kilian et al., 1998). The highest telomerase activity in plants was found in meristems and reproductive organs, whereas in endosperms, leaves, and stems there was little or no telomerase activity (Liang et al., 2014).

The shortening of telomere may result from the early stages of apoptosis (Rescalvo-Morales et al., 2016) and the occurrence of DNA damage (Ramirez et al., 2003). Environmental stress factors and physiological disorders associated with aging can increase DNA damage, especially telomeres (Watson dan Riha, 2011). Stressful plants can produce oxidative compounds, where these oxidative compounds can also speed up telomere shortening (Furumoto et al., 1998; Lorenz et al., 2001; Saretzki dan von Zglinicki, 2002; von Zglinicki, 2002). Telomeres can be a marker of apoptosis caused by an increase in oxidative compounds (Shammas et al., 2004; Granato et al., 2009). This is evidenced in the study by $\mathrm{Na}$ et al. 
(2004) on the relationship between oxidative activity of Terminalia chebula and telomere length.

\section{CONCLUSIONS}

Telomere length of snake fruit leaves were significantly different in young, older, and dried leaves. The older the leaves grow, the shorter the telomere becomes. Telomere length of snake fruit in both female and male are equal.

\section{REFERENCES}

Bernadotte, A., M.M. Victor and M.S. Irina. 2016. Markers of cellular senescence. Telomere shortening as a marker of cellular senescence. Aging., 8:1-11.

Chen, Q., A. Fischer., J.D. Reagan., L.J. Yan dan B.N. Ames. 1995. Oxidative DNA damage and senescence of human diploid fibroblast cells. Proc Natl Acad Sci., 92:4337-4341.

Fajkus, J., A. Kovarik dan R. Kralovics. 1996. Telomerase activity in plant cells. FEBS Lett., 391:307-309.

Fajkus, J., J. Fulnec `kova'., M. Hula'nova'. 1998. Plant cells express telomerase activity upon transfer to callus culture, without extensively changing telomere lengths. Mol Gen Genet., 260:470-474.

Flanary, B.E. dan W.J. Streit. 2003. Telomeres shorten with age in rat cerebellum and cortex in vivo. J Anti Aging Med., 6:299-308.

Furumoto, K., E. Inoue dan N. Nagao. 1998. Age dependent telomere shortening is slowed down by enrichment of intracellular vitamin $\mathrm{C}$ via suppression of oxidative stress. Life Sci., 63:935-948.

Granato, T., Muscoli dan A. Sgura. 2009. Apoptosis and telomere shortening related to HIV-1 induced oxidative stress in an astrocytoma cell line. BMC Neuroscience., 10:51.

Greider, C.W. and E.W. Blackburn. 1996. Telomeres, Telomerase and Cancer. Scientific American, http://www.genethik.de/telomerase.htm.

Kilian, A., C. Stiff., A. Kleinhofs. 1995. Barley telomeres shorten during differentiation but grow in callus culture. Proc Natl Acad Sci USA., 92:9555-9559.

Kilian, A., K. Heller., A. Kleinhofs. 1998. Development patterns of telomerase activity in barley and maize. Plant Mol Biol., 37:621-628.

Liang, J., C. Jiang., H. Peng., Q. Shi., X. Guo., Y. Yuan and L. Huang. 2015. Analysis of the age of panax ginseng based on telomere length and telomerase activity. Scientific Reports., 5:79-85.
Lorenz, M., G. Saretzki., N. Sitte. 2001. BJ fibroblasts display high antioxidant capacity and slow telomere shortening independent of hTERT transfection. Free Radic Biol Med., 3:824831.

Mayer, S., S.Bruderlein., S. Perner., I. Waibel., A. Holdenried., N. Ciloglu., C. Hasel., T. Mattfeldt., K.V. Nielsen., P. Moller. 2006. Sex-specific telomere length profiles and age-dependent erosion dynamics of individual chromosome arms in humans. Cytogenet Genome Res., 112:194-201.

Mu, Y., L. Ren., Z. Xun., D. Zhang., H. Song., H. Lu., F. Li and D. Liu. 2014. Sex- and season dependent differences in telomere length and telomerase activity in the leaves of ash and willow. Springer Plus., 3:163.

Na, M. K., K. H. Bae., S.S. Kang., B.S. Min., J.K. Yoo., Y. Kamiryo., Y. Senoo., S. Yokoo dan N. Miwa. 2004. Cytoprotective effect on oxidative stress and inhibitory effect on cellular aging of Terminalia chebula fruit. Phytother, Res., 18:737-741.

Pandey, S.N. dan B.X. Sinha. 1979. Plant Physiology. New Delhi: Vikas Publishing House FVT Ltd.

Purwaningsih, E. 2010. Telomer, aging dan karsinogenesis. Jurnal Kedokteran Yarsi., 18:137-143.

Ramirez, R., J. Carracedo dan Jimenez. 2003. Massive Telomere loss is an early vvent of DNA damage-induced apoptosis. J Bio Chem., 272:836-842.

Rescalvo-Morales, A., K. M. Monja-Mio., G. HerreraHerrera., M.L. Robert., L.F. Sa'nchez-Teyer. 2016. Analysis of telomere length during the organogenesis induction of Agave fourcroydes Lem and Agave tequilana Weber. Plant Cell Tiss Organ Cult., 127:135-143.

Riha, K., J. Fajkus., J. Siroky dan B. Vyskot. 1998. Developmental Control of Telomere Lengths and Telomerase Activity in Plants. The Plant Cell., 10: 1691-1698.

Saretzki, G. dan T.V. Zglinicki. 2002. Replicative aging, telomeres and oxidative stress. Ann $N$ Y Acad Sci., 959: 24-29.

Sestak, Z. 1981. Leaf Ontogeny and Photosynthesis, Physiological Processes Limiting Plant Productivity. London: Butterworths.

Shammas, M.A., H. Koley., D.G. Beer., C. Li, A.K. Goyal dan Munshi. 2004. Growth arrest, apoptosis, and telomere shorttening of Barrett's associated adenocarcinoma cells by a telomerase inhibitor. Gastroenterology., 126:1337-1346. 
Shay, J.W., Y. Zou., E. Hiyama and W.E. Wright. 2001. Telomerase and Cancer. Hum Mol Gen., 10: 677-685.

Song, Y.S., B.Y. Lee and E.S. Hwang. 2005. Dinstinct ROS and biochemical profiles in cells undergoing DNA damage-induced senescence and apoptosis. Mech. Ageing Dev., 126:580-590.

Song, H., D. Liu., X. Chen., Z. Ying., B. Zhang., F. Li., and H. Lu. 2010. Change of season-specific telomere lengths in Ginkgo biloba L. Mol Biol Rep., 37:819-824.

Susanto, A. 2008. Kadar Klorofil pada Berbagai Tanaman yang Berbeda Umur. Surabaya: Jurusan Biologi Fakultas Matematika dan Ilmu Pengetahuan Alam, Universitas Negeri Surabaya.
Suyatma. 2009. Diagram warna hunter (kajian pustaka). Jurnal Penelitian Ilmiah Teknologi Pertanian., 8-9.

Von, Z.T. 2002. Oxidative stress shortens telomeres. Trends Biochem Sci., 27: 33-344.

Wahyuni, D.T. dan S.B. Widjanarko. 2015. Pengaruh jenis pelarut dan lama ekstraksi terhadap ekstrak karotenoid labu kuning dengan metode gelombang ultrasonic. Jurnal Pangan dan Agroindustri., 3:390-401.

Watson, J.M. dan K. Riha. 2011. Telomeres, aging, and plants: from weeds to Methuselah: a mini-review. Gerontology., 57:129-136.

Wolf, J. dan L. Price. 1960. The effect of sugars on chlorophyll biosynthesis in higher plants. $J$. Biol. Chem., 235:1603-1608

Wong, I.M. and K. Collins. 2003. Telomere maintenance and disease. Lancet., 362: 983-988. 